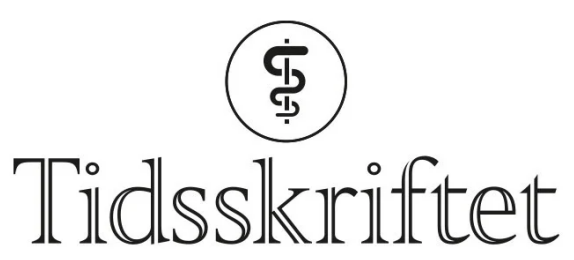

DEN NORSKE LEGEFORENING

\title{
H. Waal og medarbeidere svarer
}

\author{
KOMMENTAR \\ HELGE WAAL \\ helge.waal@medisin.uio.no \\ Helge Waal er professor emeritus.
}

JØRN HERIK VOLD

SVETLANA ONDRASOVE SKURTVEIT

Ingen av forfatterne har oppgitt noen interessekonflikter.

Vi er godt kjent med den studien av kvetiapinforskrivning Gjerden og Slørdal refererer til. Som de skriver, fikk 9o,5\% forskrevet lavere doser enn svarende til definerte døgndoser for de aksepterte indikasjonene. Dette peker mot en betydelig bruk "off label» men ikke i seg selv mot bruk til rusformål eller som følge av avhengighet. I sin kommentar fremhever forfatterne at 9,5\% har forskrivning svarende til anbefalt behandling av psykoser eller affektive lidelser. Det de er opptatt av at vel halvdelen av forskrivningene har skjedd på hvite resepter og bare halvdelen på blå. De mener at dette peker mot misbruk.

Valg av resepttype bestemmes av forskrivende leger, ikke av pasienten. Vi har ingen informasjon om disse legenes motiver eller forskrivningsatferd. Det er en rekke mulige forklaringer, og vi opplever det spekulativt å tilskrive reseptvalget til misbruksdiagnose. Vi vil generelt anbefale forsiktighet i tolkningen av reseptdata til pasient- og legeatferd. Vil dessuten ønske oss en avklaring av hva Gjerden og Slørdal mener med begrepene misbruk og avhengighet, og peker for øvrig mot at få, om noen, av tilbakemeldinger fra rusfeltet sannsynliggjør bruk for euforiserende formål eller som ledd i avhengighetssyndrom.

Publisert: 28. september 2020. Tidsskr Nor Legeforen. DOI: 10.4045/tidsskr.20.0705

(C) Tidsskrift for Den norske legeforening 2023. Lastet ned fra tidsskriftet.no 26. april 2023. 